Proc. Estonian Acad. Sci. Biol. Ecol., 2001, 50, 2, 85-109

\title{
HISTORY OF LATVIAN FISHERIES RESEARCH
}

\author{
Māris VĪTIN̦Š, Ritma GAUMIGA, and Andis MITĀNS
}

Latvian Fisheries Research Institute, Daugavgrivas 8, LV-1007 Riga, Latvia; m_vitins@latfri.lv, library@1atfri.lv, mitans@latfri.lv

Received 28 March 2001, in revised form 16 April 2001

\begin{abstract}
The history of the development of Latvian fisheries research and marine investigations connected with it is described, starting with the 18th century. The development of research fields and institutions, the role and achievements of main scientists involved, most important publications, and the place of Latvian fisheries science in national and international research community are shown. During the 18th-19th centuries mainly the accumulation of knowledge on the fauna, flora, and water environment of Latvian coastal sea and inland waters, fishery, and aquaculture by naturalists and scientists took place. The First International Baltic Sea Fisheries Congress in 1910 in Riga promoted the investigations on fish fauna and fishery regulation in the Baltic Sea. Since the first years of the independent Republic of Latvia, the Ministry of Agriculture organized regular fisheries and marine investigations in the Gulf of Riga and the open Baltic Sea and established research cooperation with other Baltic Sea countries. In 1923 Latvia became an associated member and in 1937 a full member of the International Council for the Exploration of the Sea (ICES). Since 1945 the Latvian fisheries and marine research was concentrated in one institution, further developed as the Latvian Fisheries Research Institute expanding the regular surveys in the whole Central Baltic Sea, including the Gulf of Riga, and inland waters, and covering a wide spectrum of research, monitoring, and modelling, including the environment, hydrobiology, fish resources, fishery, and aquaculture. The Institute maintains intense research cooperation with other countries and within international organizations - ICES, International Baltic Sea Fisheries Commission, Helsinki Commission, and others.
\end{abstract}

Key words: fisheries/marine research, history, Latvian Fisheries Research Institute.

\section{INTRODUCTION}

From ancient times, fishery and seafaring have been important economic activities of people inhabiting the present-day territory of Latvia. This has facilitated the accumulation of knowledge about waters and aquatic life, in latest centuries developing into the fisheries science, which nowadays is supporting the 
economically and socially important fisheries sector of Latvia, as well as making a valuable contribution to research into the Baltic Sea ecosystem and environmental protection. In the present paper the development of research directions, growth of research institutions, role and achievements of main scientists involved, most important publications, and the place of Latvian fisheries science in national and international research community are shown.

\section{BEFORE 1918}

Fishery as a traditional economic activity in Latvia has a history of thousands of years, as shown by archeological investigations at the sites of the first human settlements on the territory of Latvia (Sloka, 1985). Knowledge about waters and the aquatic life was needed for everyday life of Latvian population with old seafaring traditions. The dates of the beginning and break of ice cover in Latvian rivers, of ice jams and floods in the lower reaches of the Daugava River have been registered already since 1530 (Stakle, 1931).

Information on owners of waters, valuable fishing grounds, conservation measures of fish resources, fishing and fishery in estates on the territory of Latvia, in Kurland and Livland, and adjacent waters before the 18th century can be found in archive documents of the Russian Empire, in records of churchbooks, etc. (Cimermanis, 1998).

The first descriptions of water plants, animals, and fishing in Latvian inland waters and coastal sea are given by historians and naturalists of the end of the 18th - beginning of the 19th century: August V. Hupel, Johan K. Broce, and others. The book Versuch einer Naturgeschichte von Livland by J. B. Fischer (1791) was the first scientific overview of local flora and fauna, including descriptions of 48 fish species and presentation of their Latvian names. His work can be considered the beginning of ichthyology in Latvia.

The second half of the 19th century was characterized by rapid intensification of utilization of fish resources in Europe, including the Baltic Sea region. The first signs of overfishing were found or alleged here and there. This led to internationalization of marine research, especially of the research on fish stocks. For coordinated investigations in marine fisheries and oceanography the International Council for the Exploration of the Sea (ICES) was established in 1902. This organization had a crucial role in the further development of fisheries research in the Baltic Sea.

In the second half of the 19th century the Russian Empire was paying special attention to the fishery in the Baltic region. In the Das Inland and Baltische Wochenschrift important articles on hydrobiology, fishing, gear, and causes of decreasing fish resources were published by Johan Kawall (1857), Gothard Schweder (1884), and Max von zur Mühlen (1903). The scientific works within the frames of the Riga Naturalists Society, founded in 1845 and headed by naturalists 
and teachers Gothard Schweder (1831-1915), Karl Kupffer (1846-1942), and others as presidents, were published in the issues of the Korrespondenzblatt des Naturforscher - Vereins zu Riga (1845-1942) or in the Arbeiten des Naturforscher - Vereins zu Riga (1847-1948). The summarizing publications on zoogeography, fish fauna, and fishery by Guido Schneider $(1925,1928)$, on the morphometry, hydrochemistry, and hydrobiology of lakes by Ferdinand Ludwig (1908) and K. Kupffer (1925) deserve special mentioning. The Naturalists Society of Riga also performed the monitoring of water level in the Daugava River and the Riga Port (1874-1916).

During the second half of the 19th century and the first half of the 20th century two large expeditions were organized by Russia in the Baltic Sea, including Latvian coastal waters: in 1851-52, headed by Karl Ernst von Baer and Nikolai Danilevskij, and in 1908-09, led by Oskar Grimm and Evgenij Suvorov. The expeditions collected data on temperature, salinity, oxygen, hydrobiology, fish, and fishery.

In 1912 P. Borisov, fulfilling the tasks of the Vidzeme Department of the Imperial Russian Society of Fish Culture and Fisheries, investigated the fisheries economics in the Riga District, which was an area of the most intensive fishery in Latvia during the period 1875-1912.

In 1910 the First International Baltic Sea Fisheries Congress was held in Riga. Among the participants were also fisheries scientists and administrators G. Schneider, D. Phil., Director of the Riga Polytechnic (RP); Rudolf Meyer, Mag. Phys., Ass. Prof. of the RP; Gothard Schweder, President of the Riga Naturalists Society; A. Bandrewitsch and R. Streiff from Riga; M. von zur Mühlen and A. Kirsch from Tartu; and Prof. N. M. Knipowich from St. Petersburg. The Congress emphasized the importance of investigations of the Baltic Sea fauna, and of the regulation of fishery for salmon, sea trout, eel, flatfishes, herring, and sprat. The need to increase research in the Gulf of Riga was pointed out. Simultaneously with the Congress, the All-Russian Exhibition of Aquaculture and Fishery, showing also fishing gear and equipment for marine research, took place in Riga.

\section{8-40}

After World War I, since the first years of the independent Republic of Latvia, reorganization of fisheries and the marine research connected with it was started. Latvia was entering the system of international coordination of marine and fisheries research and regulation of fisheries, which was developing in the Baltic Sea. For this appropriate institutional framework and organization of regular environmental, biological, and fishery data collection were needed.

In 1920 the conference of coastal states of the Baltic Sea, held in Bulduri (a health resort near Riga), considered cooperation with ICES. In 1921 in Tallinn experts from Latvia Valdemārs Miezis (Photo 1) and Prof. R. Meyer together with 


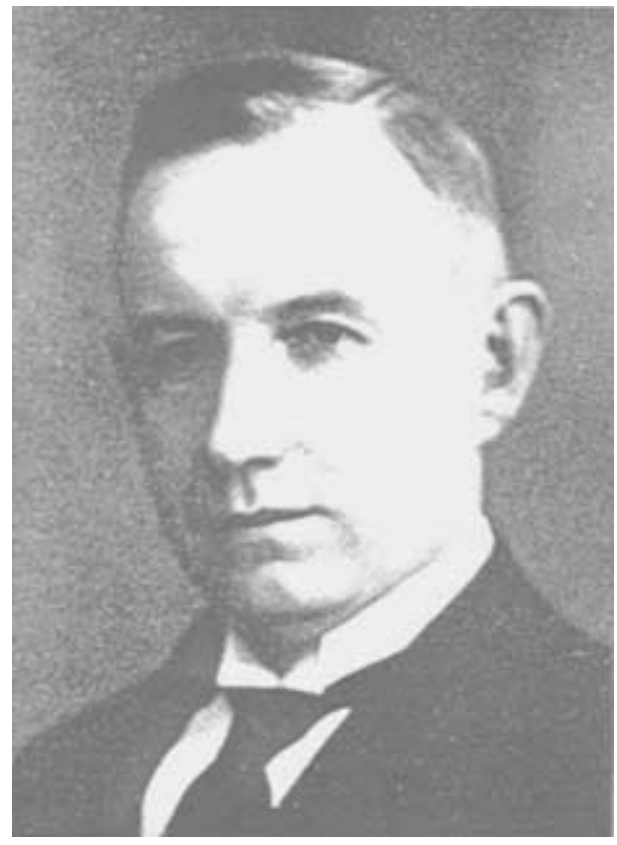

Photo 1. Valdemārs Miezis (1893-1975).
Estonian and Finnish scientists made practical decisions on arrangement of fishery statistics, investigations of fish stocks, and collaboration in hydrographic and plankton surveys in line with recommendations of ICES. In the same year V. Miezis participated in the ICES Statutory Meeting in Copenhagen as an observer from Latvia. In 1923 Latvia was accepted by all ICES contracting parties as an associated member of this organization and since 1937 Latvia got rights of full member of ICES with V. Miezis as the Latvian delegate and the representative of Latvia in the Baltic, Hydrography, Plankton, Limnology, Salmon and Sea Trout, and Statistics committees. Since then Latvian scientists have regularly presented contributions to ICES proceedings and reports.

In the internal organization of marine research in Latvia initiative was taken by the Ministry of Agriculture. In 1921 the Commission on Research of Latvian Waters was created at the Department of Fishery and Fish Culture of the Ministry. The tasks of the Commission were to fulfil the recommendations of the Tallinn Conference. Parallel to the Commission, the Hydrobiological Laboratory at the Ministry of Agriculture was established to start regular environmental and fisheries research. The research on growth, migrations, and catch structure of salmon, whitefish, and smelt as well as on artificial reproduction of salmon and whitefish were initiated (Mansfeld, 1928, 1930; Mansfelds, 1936). In 1923 the network of coastal observation stations was established, and in the next year the first regular hydrographic surveys were made on board the steamer Hidrogräfs in the Gulf of Riga and the open Baltic Sea. In 1924, by a governmental decision, the Hydrobiological Laboratory was transferred to the University of Latvia, and on its basis the Hydrobiological Station was established with Prof. Embrik Strand as director. The tasks of the station included continuation of research for fisheries needs. In connection with this hydrographic surveys by the Department of Fishery and Fish Culture of the Ministry of Agriculture stopped till 1931, and then were resumed.

In 1924 the Hydrobiological Station started monthly measurements of water temperature and salinity using ships of opportunity on the regular lines Helsingborg-Riga, Riga-Kiel, Kiel-Danzig-Riga, Liepaja-Riga, and AinažiRiga. The State Meteorological Agency performed regular registration of water temperature and ice conditions, and the Hydrographic Department of the Ministry 
of Finance, regular water level registration in seven coastal stations. An important contribution to the creation of the basis of hydrologic research was made by P. Stakle, R. Meyer, and L. Slaucītājs.

The Hydrobiological Station investigated abiotic conditions and biota in marine waters and lakes - hydrology, hydrochemistry, plankton, benthos, and fish fauna, with important input by hydrobiologists Prof. Embrik Strand and Viktors Ozoliņ̌s (Strand \& Ozoliņš, 1931-34). In 1925-34 V. Ozoliņš headed hydrobiological investigations in Lake Usma (Ozolinšs, 1930). Later on similar investigations were performed in the area of the estuary of the Gauja River and in lakes of Southern Latgale by Bruno Bērziņš and Nikolajs Sizovs. B. Bērziņš published articles on hydrographic surveys in the Gulf of Riga and the open Baltic Sea, as well as on freshwater and marine fish (Bērziņš, 1937; Berzins, 1942).

Thorough investigations on zooplankton productivity as the basis of fish food were carried out by M. Rapoport and B. Bērzinšs. The long-term hydrobiological data collected in the 1920s-30s enabled a substantial improvement of the information on the fauna and flora of the Baltic Sea.

Results of research in ichthyology and hydrobiology were published in the proceedings of the University of Latvia Folia Zoologica et Hydrobiologica (1929-43), in the journals Daba (Nature, 1924-31), Daba un zinātne (Nature and Science, 1934-40), and in the publication of the Geographical Society Folia Geographica (1929-38).

In connection with the construction of a large state fish hatchery "Tome", the Fisheries Laboratory at the Department of Fishery and Fish Culture of the Ministry of Agriculture was established, with the task to develop all relevant research directions and to create scientific basis for an effective functioning of hatcheries: to experiment with intensive rearing of salmonids in artificial basins, to study fish diseases and development of abnormalities, and to investigate fish migrations using tagging. Research on the stock size of herring, growth rate and sex structure of eel, distribution of flounder along the Latvian coast, and most important commercial fish populations was developed.

In 1930 the Fisheries Laboratory started chemical and technological investigations to elaborate methods for the production of fish preserves and impregnation of fishing gear. Also, pollution of waters from paper mills and sugar factories and with oil was considered. From 1927 to 1930 a complex research including water pollution and self-purification was carried out applying hydrobiological methods in the area of the Daugava River estuary. Later on a special commission on pollution control, which involved specialists from the Fisheries Laboratory and the Hydrobiological Station, was established.

Regular collection of standardized fishery statistics was started in 1924, and published since 1926 in the Bulletin Statistique des Peches Maritimes de Lettonie, edited by V. Miezis, as well as in ICES statistical editions. From 1924 to 1938 the monthly data on catches by species, regions, and gear, on the number of fishermen, fishing boats, and gear, fish market prices, as well as on the number of killed seals were published. The data are very important from the point of view of fisheries management and research. A general overview on the state of the fisheries sector in Latvia at the end of the 1930s was produced by Pauls Ludvigs (Ludvigs, 1940). 
The results of fisheries investigations in Latvia in the pre-war period were published in the ICES editions Journal du Conseil International pour l' Exploration de la Mer and Bulletin Hydrographique, as well as in the Latvian publications Zvejnieku vēstnesis (Fishermen's Bulletin, 1922-33) and Zvejniecības mēnešraksts (Monthly Fisheries Magazine, 1937-40).

\section{5-91}

This period is characterized by stepwise development of comprehensive fisheries and marine research in Latvia, including the institutional strengthening, organization of regular surveys on board research vessels, building up long-term databases, and development of international cooperation in the management of marine resources. In this period practically all Latvian fisheries research and the related environmental investigations were concentrated into one institution. Its birth date is 17 May 1945, when based on the former Fishery Laboratory, the Latvian Department of the All-Union Research Institute of Marine Fisheries and Oceanography (VNIRO) (Photos 2 and 3) was established in Riga. The work

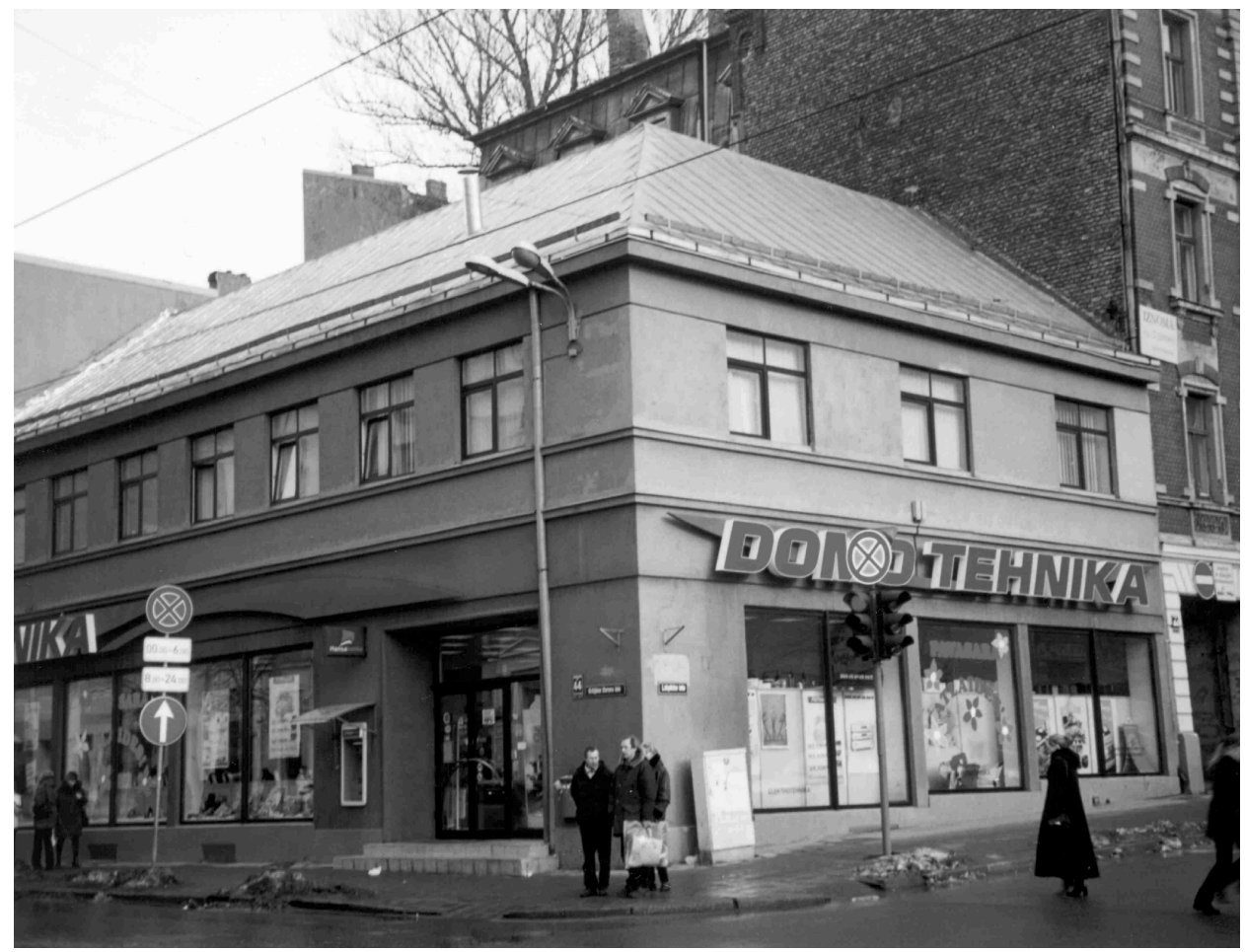

Photo 2. From 1945 to 1948 the Latvian Department of VNIRO was situated on the second floor of this building in 44 Krišjāṇa Barona Str. in Riga. 


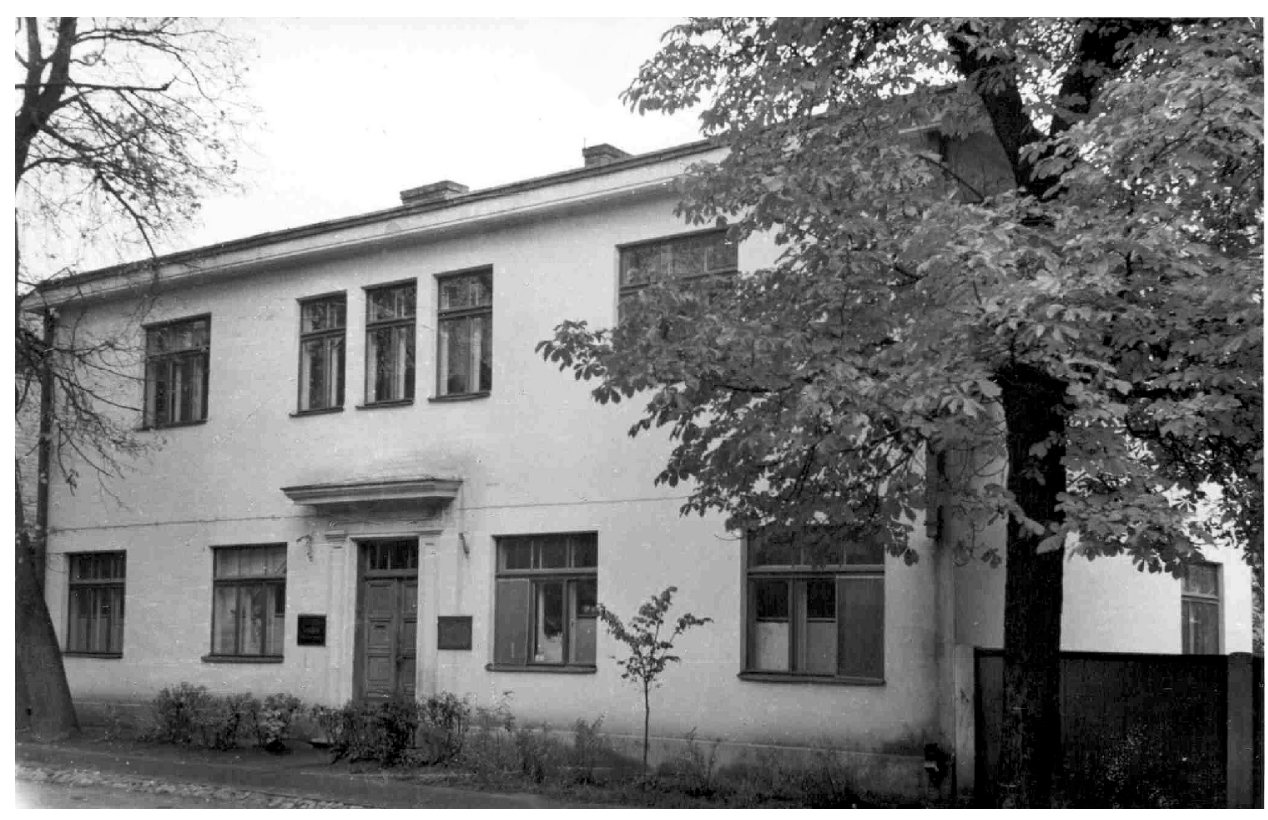

Photo 3. Building of the Latvian Department of VNIRO and later of the Baltic Fisheries Research Institute in 1 M. Bezdelīgu Str. in Riga from 1948 to 1973.

started with 15 researchers and assistants in three laboratories - of Ichthyology, Oceanography, and Technology. From the very beginning the Latvian Department of VNIRO started the complex monitoring type surveys in the Gulf of Riga and the open Baltic Sea on hydrology, hydrochemistry, phytoplankton and zooplankton, ichthyoplankton and benthos, as well as on the distribution, feeding, growth, and spawning success of cod, herring, sprat, and flounder. In 1947 six field stations for coastal observations were established (in Liepāja, Ventspils, Kolka, Mçrsrags, Lielupe, and Skulte) and log-books were introduced in the Latvian fishing fleet. The Department had to supply the fishery with regular maps on the distribution of fish stocks. Already in 1947 the surveys covered the area of the Baltic Sea from the Gulf of Gdansk to Saaremaa Island.

To evaluate the feeding and spawning areas of cod, herring, sprat, and flounder, to assess their stocks, and to evaluate the opportunities to develop fishery for these species, in 1948-49 a framework named the "Baltic Complex Expedition" was organized by VNIRO. The Latvian Department had an important input in it (VNIRO, 1954).

During the following years the Institute's capacity grew. Complex research was developed, but the main tasks and goals remained the same - to supply the Latvian fishery and fisheries administration with relevant scientific data on the environment and fish resources, including the effect of fisheries and the regulation measures. 
On 8 October 1959 the Latvian Department of VNIRO was reorganized into the Fisheries Research Institute (NIIRH) and on 11 December 1962 into the Baltic Fisheries Research Institute (BaltNIIRH) (Photo 4). In the 1980s BaltNIIRH grew into a large regional institute of the Baltic Basin with more than 200 employees and 15 laboratories, responsible for comprehensive research on oceanography, hydrochemistry, hydrobiology, demersal and pelagic fish stocks, fishing regulation and technology, aquaculture and artificial restocking, coastal and inland waters, mathematical modelling, fish processing technology, and fisheries economics. It had a computerized Data and Information Centre. From 1963 to 1991 the Estonian Laboratory of Marine Ichthyology was subordinated to BaltNIIRH as a department. During that period the director of BaltNIIRH was Mihail Polyakov, a specialist in fishing technology. He played an important role in the evolution of the fisheries research in Latvia.

Already since 1946 the marine research of the Latvian Department and further of BaltNIIRH was supported by the following expedition and research vessels: MPT-48 (31 m long, operating from 1947 to 1950), Liepāja (31 m, 1948-53), CPT-129 (38 m, 1951-55), Mazirbe (39 m, 1958-78), Besspokojnij (32 m, 1967-87), MPTP-0027 (32 m, 1972-85), Zvezda Baltiki (55 m, 1977-91), and Issledovatel Baltiki (later Baltijas Pētnieks, 55 m, 1984-93) (Photos 5-10).

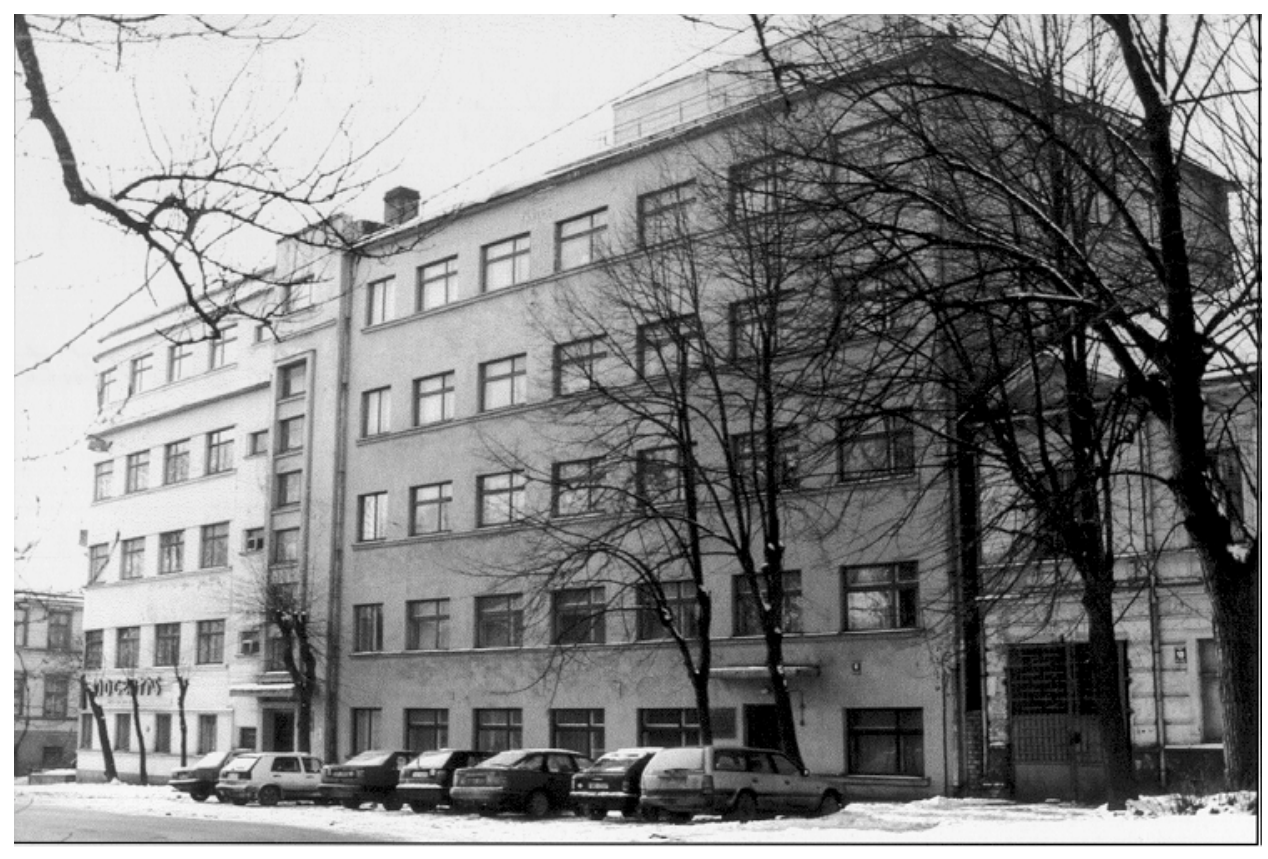

Photo 4. Building of the Baltic Fisheries Research Institute and later of the Latvian Fisheries Research Institute in 6/8 Daugavgrīvas Str. in Riga since 1973. 


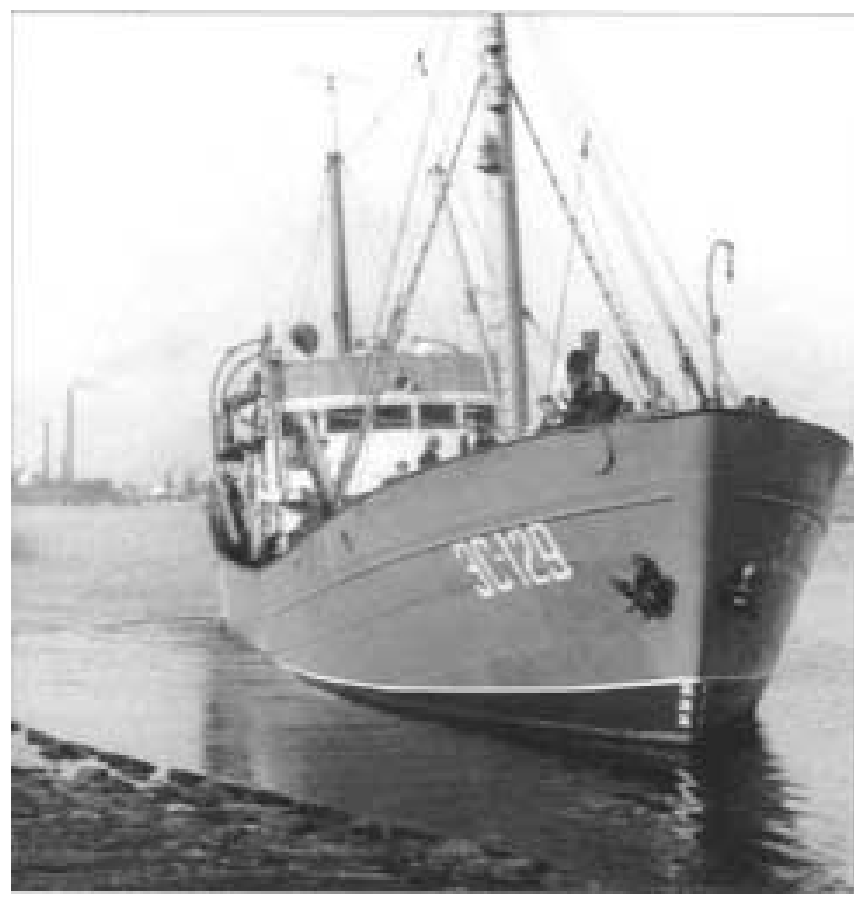

Photo 5. R/V CPT-129.

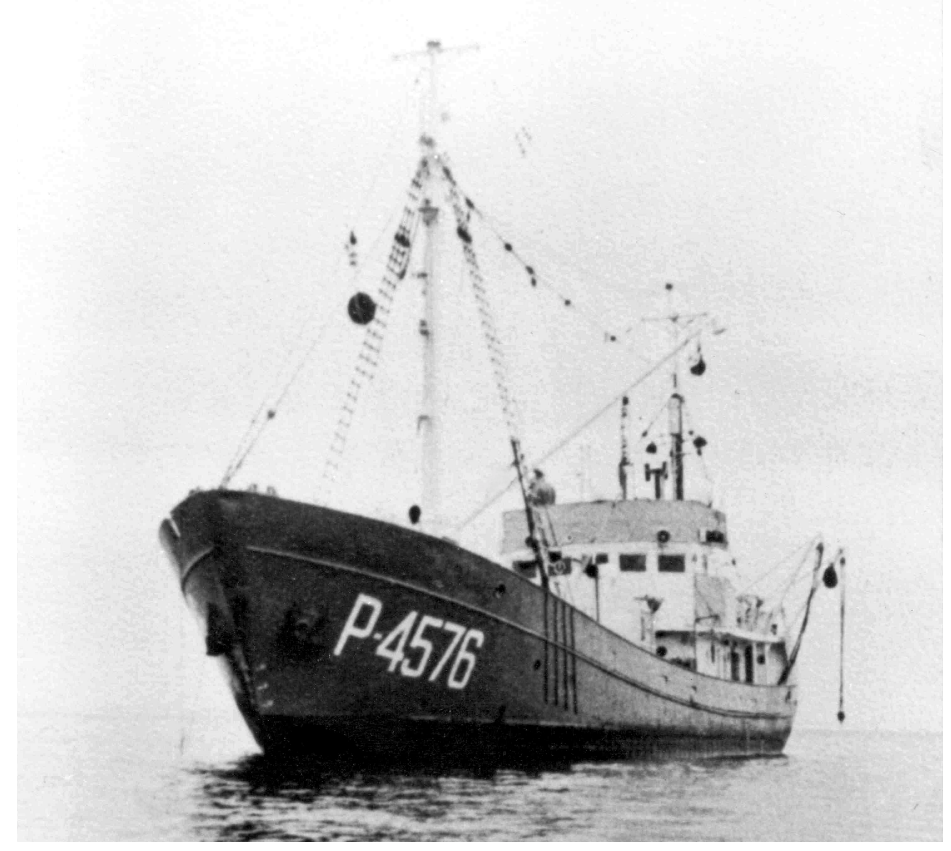

Photo 6. R/V Mazirbe. 


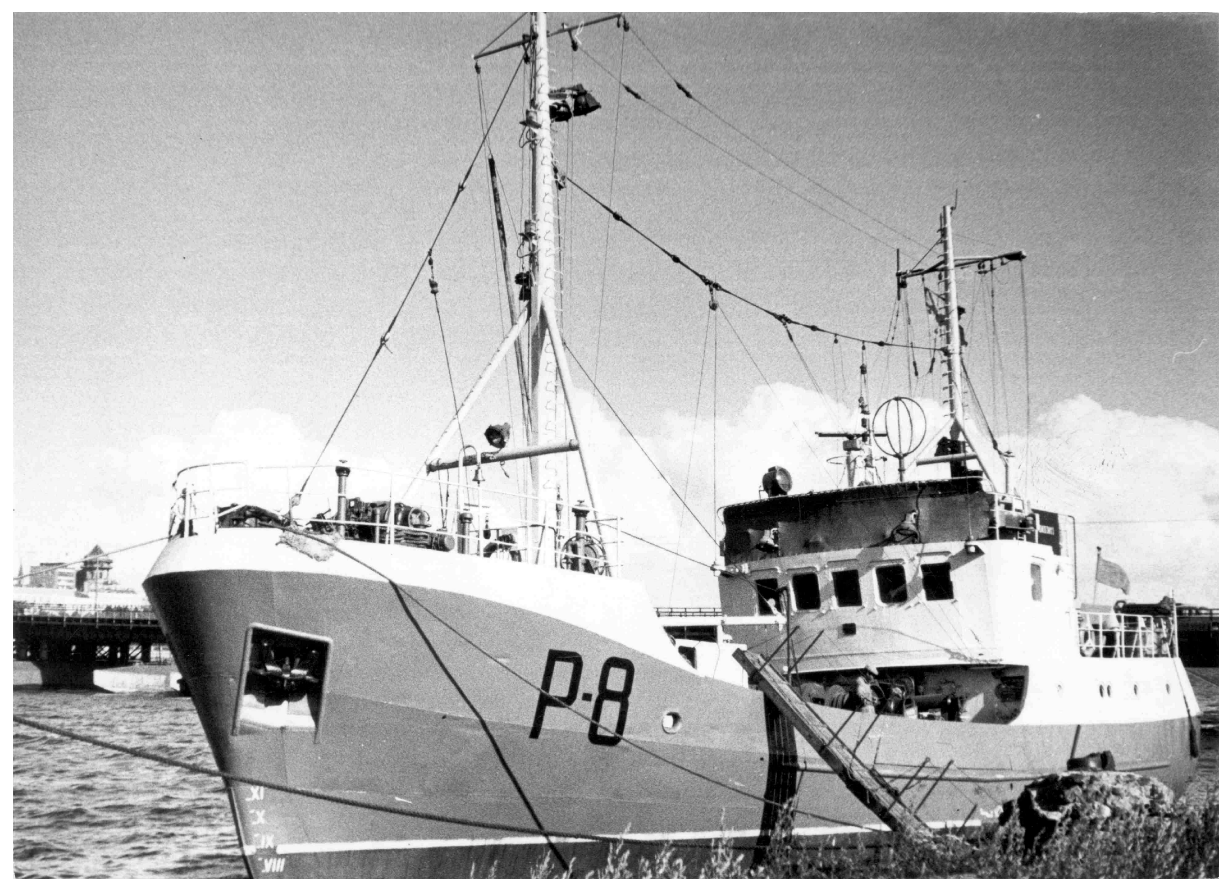

Photo 7. R/V Besspokojnij.

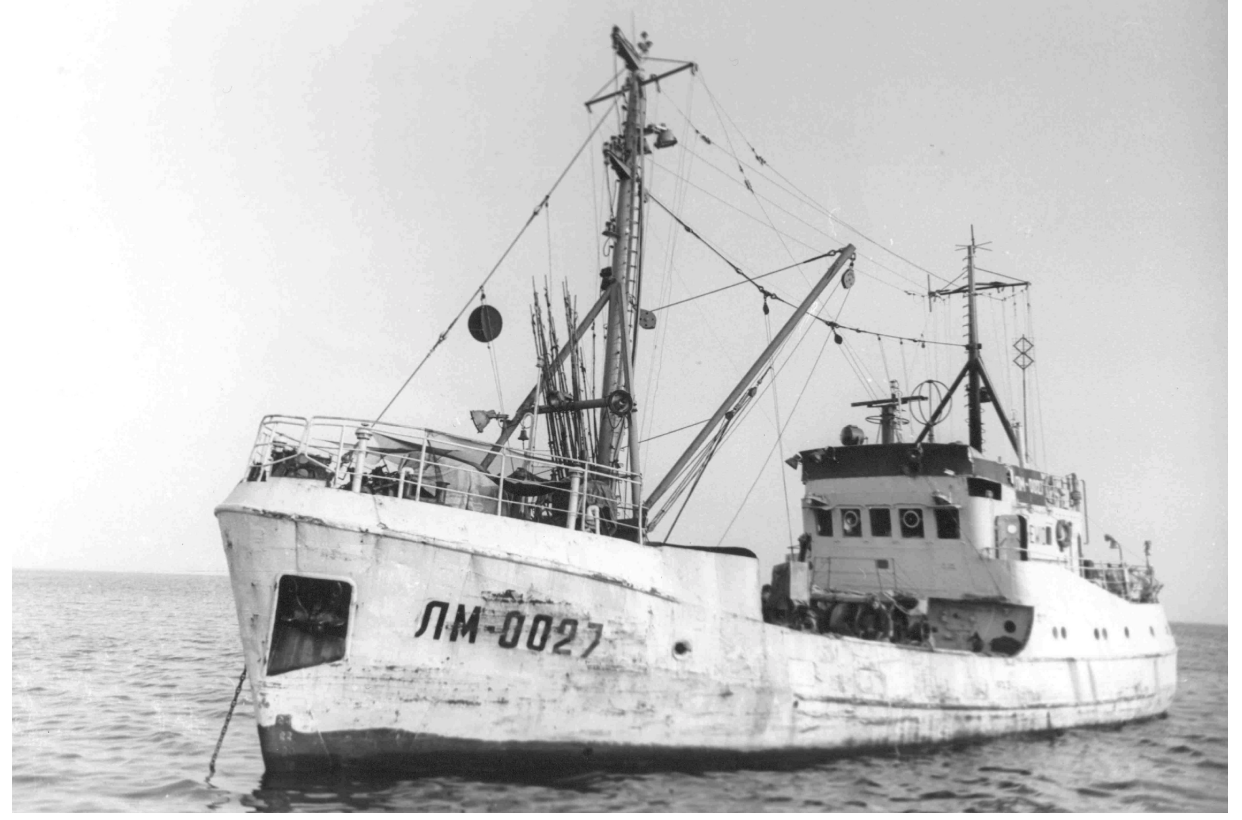

Photo 8. R/V MPTP-0027. 


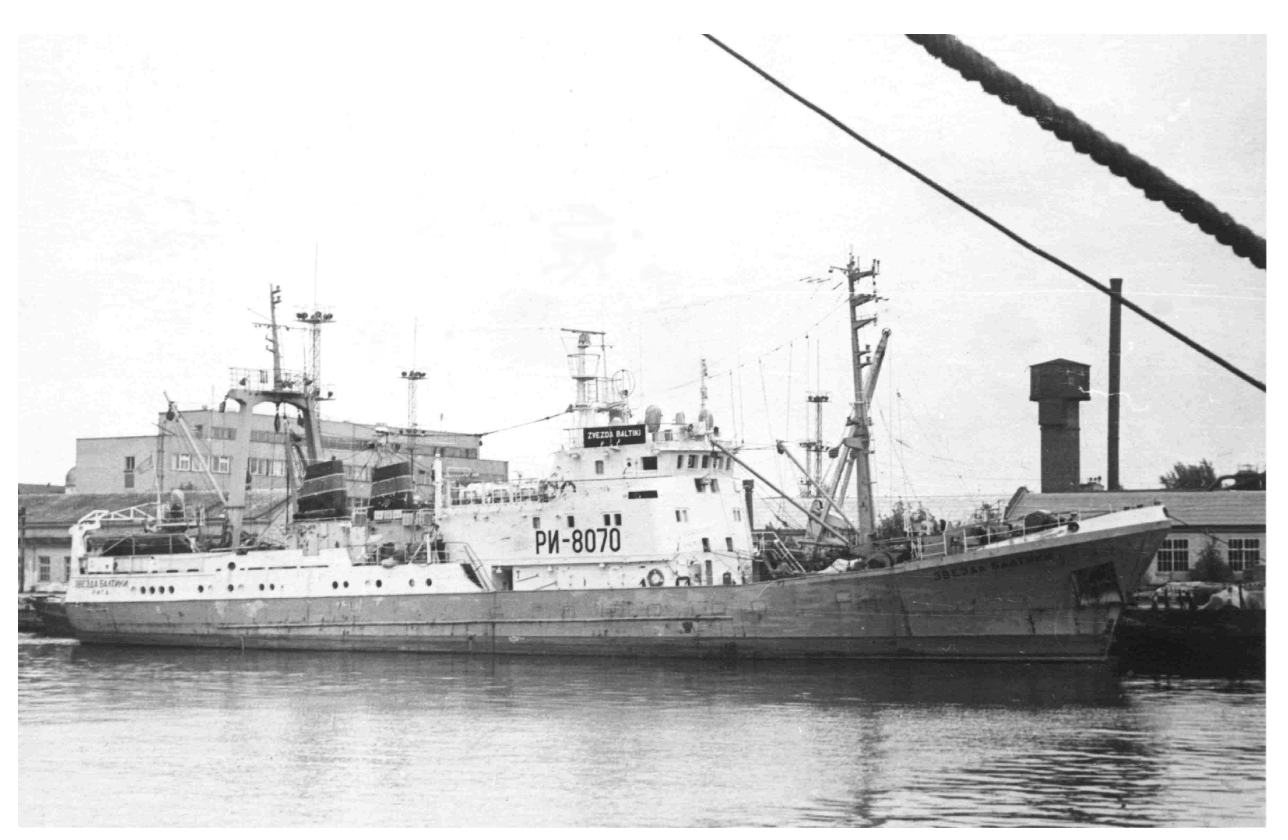

Photo 9. R/V Zvezda Baltiki.

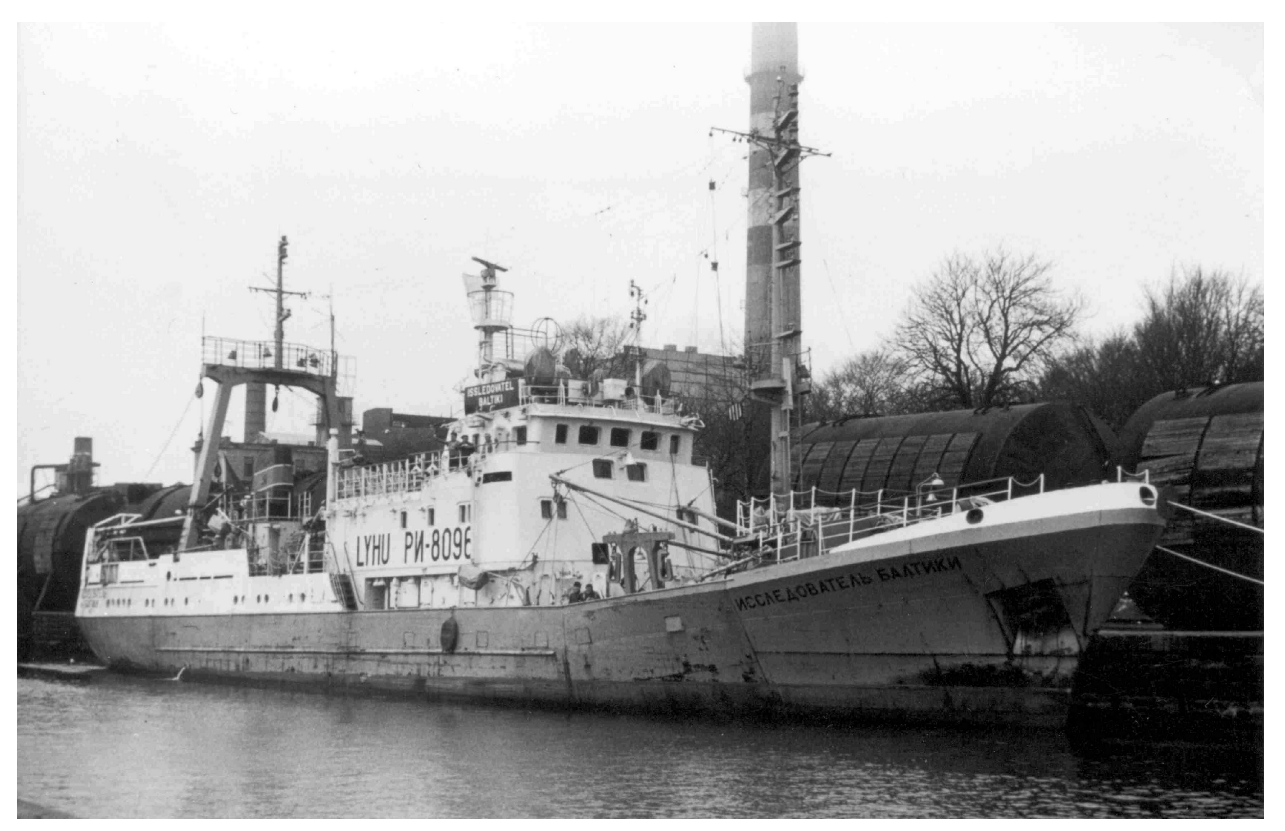

Photo 10. R/V Issledovatel Baltiki (later Baltijas Pētnieks). 
This fleet enabled to cover by comprehensive monthly or seasonal surveys the whole Central Baltic area from the Bornholm Basin in the south to the Gulf of Finland in the north. In 1956-59 the Institute performed several surveys in the North Sea to contribute to the investigations on the reasons for the reduction of herring stocks in this area. After the introduction of national economic zones in the Baltic Sea in 1978, the research of BaltNIIRH was concentrated mainly in the waters of the Soviet Union. The Institute has composed systematic databases on cod feeding in the Baltic Sea since 1949, on zooplankton and fish stocks since 1958, on hydrology and hydrochemistry since 1961, on ichthyoplankton since 1970, on herring and sprat feeding since 1976, on hydroacoustics of pelagic fish since 1977, and on macrophytobenthos since 1981. In the 1960s zooplankton sampling was also performed on a research vessel of the Latvian State Hydrometeorological Agency - the Ģeofizikgis (25 m). Since 1974 BaltNIIRH had a Coastal Research Station at Roja and part of the surveys in the Gulf of Riga were carried out on board commercial $15 \mathrm{~m}$ fishing boats Māra and Nāra of the cooperative "Banga" at Roja, on boats of the fishing cooperatives "Brīvais Vilnis" in Salacgrīva and "Zvejnieks" in Zvejniekciems, and on the specially equipped $15 \mathrm{~m}$ fishing boats Ruhnu and Vaal belonging to the Estonian fishing cooperative "Pärnu Kalur".

Research results were published in the following regular Russian language publications of the Institute: Proceedings of Latvian Department of VNIRO, Vols. 1 and 2 (1953-57), Proceedings of Baltic Fisheries Research Institute, Vols. 3 and 4 (1961-70), Proceedings of BaltNIIRH: Fisheries Research in the Basin of the Baltic Sea, Nos. 1-18 (1966-83), as well as in special editions dealing with artificial reproduction of rainbow trout and salmon, river lamprey, intensive cultivation of salmonids, diseases of fish in ponds, etc.

In the 1940s and 1950s the transition from biostatistical analysis to causal analysis of the dynamics of fish stocks, based on the environmental and feeding conditions, took place. The founders of this school in Latvian fisheries research were Ivan Nikolaev, D. Biol., and Mstislav Lishev, Cand. Biol. A significant input into the research of links between the benthic communities and fish was given by Austra Shurin, Cand. Biol. The relationship between the environment and reproduction success of herring was analysed by Lidia Lisivnenko, Cand. Biol. The school of comprehensive research on artificial reproduction and restockings of migratory fish in Latvia was founded by Elena Malikova, D. Biol. Research on fishing techniques was started by Vasilij Kanin and Kir Yudanov and on fish processing technology by Polina Pozhogina. In this period the collaboration with leading scientists of VNIRO was very close.

I. Nikolaev (Photo 11), who worked at the Institute from 1946 to 1963, was a founder of research into fisheries oceanography in Latvia. He described the dynamics of the productivity of various elements of the Baltic ecosystem, including cod, herring, and sprat, and its relationship to fluctuations of salinity, temperature, and runoff of rivers. Also, he defined the biological seasons of 
planktonic communities, and in collaboration with Hermīne Krievs, Velta Bodniece, and Jānis Sloka, the links between the zooplankton composition, abundance, distribution, and the feeding and distribution of different populations of Baltic herring and sprat. I. Nikolaev presented the first comprehensive analysis of phytoplankton communities in the Gulf of Riga, their species composition, seasonal, vertical, and horizontal distribution, and productivity in comparison with southern and arctic seas. He was the first to analyse the causes and consequences of blue-green algal "blooms" in the Baltic Sea. He described 83 fish species and their economic importance in Latvian waters (Nikolaev, 1953a,b, 1957a,b, 1961).

I. Nikolaev's direct successors in the fisheries research were: Marğers Kalējs in oceanography, Natalia Aleksandrovskaya, Cand. Biol., and Aivars Jurkovskis, Cand. Biol., in hydrochemistry and phytoplankton research, and Elena Kostrichkina, Cand. Biol., in hydrobiology

M. Kalējs was a leading scientist in the research on regularities and short-term and long-term forecasting of the climatic and oceanographic regime of the Baltic Sea and its influence on fish resources (Kaleis \& Tamsalu, 1975; Kaleis \& Ojaveer, 1989). In the 1980s, in collaboration with the Academy of Sciences of the Estonian SSR, a fundamental research project on modelling short-term biological processes was implemented. In the 1960s-80s also Arkadij Antonov,

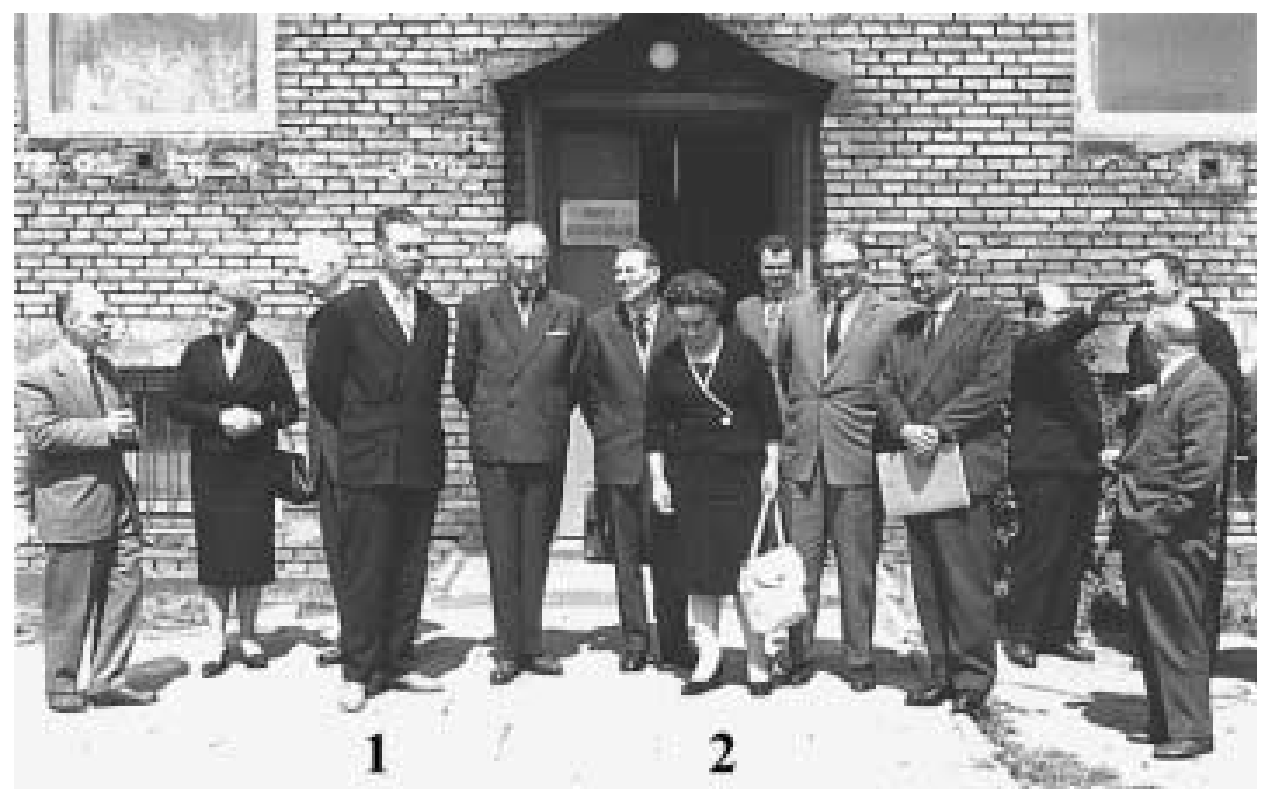

Photo 11. The participants in the meeting of fisheries experts from the USSR and Poland in the Polish Sea Fisheries Institute in Gdynia in 1962. 1, Ivan Nikolaev and 2, Elena Malikova from the Baltic Fisheries Research Institute. 
Cand. Biol., Edmunds Jūla, and Viesturs Bērziņš made contributions to the oceanographic research in Latvia. In the same period A. Jurkovskis and his group (Baiba Kalveka, Baiba Modre-Jansone, Anda Bramane, Biruta Grotāne-Lismane, Miķelis Mazmačs, and others) had an important role in the investigations on hydrochemistry and primary productivity in the Baltic Sea.

During the second half of the 1960s the complex of hydrochemical research was widened with investigations on the organic substances and phytoplankton added. Efforts were made to differentiate the natural processes from the anthropogenic influence in the Baltic Sea. In the 1980s the research on toxicants in marine waters was initiated. The results are presented in numerous publications on the structure of nutrients, their loads and budget in the Baltic ecosystem, on organic substances and chemical processes in the marine environment, on the trends in the primary productivity, and interrelationships with the dynamics of zooplankton.

During 1974-91 E. Kostrichkina, together with Skaidrīte Freimane-Apine, Maija Vītiņa, Ritma Līne, and Ludvigs Sidrēvics, made an important contribution to comprehensive analysis of ecologic complexes, long-term dynamics and forecasting of the productivity and composition of zooplankton in relation to the environmental factors in the Baltic Sea and the Gulf of Riga, as well as to the role of zooplankton in feeding and growth of fish (Kostrichkina, 1968; Kostrichkina et al., 1982, 1989).

Austra Shurin, Cand. Biol. (Photo 12), devoted her scientific work to fisheries from 1946 to 1970. She was the first director of the Latvian Department of VNIRO. On the basis of complex analysis of species composition and distribution of benthic fauna, she pioneered in defining and mapping different types of benthos communities of the Gulf of Riga and describing their role in the distribution and state of demersal fishes with special reference to flounder (Shurin, 1957, 1961, 1968).

In the 1970s Galina Shvetsova investigated the biology, distribution, and abundance dynamics of relict and arctic mysids in the Gulf of Riga and the open eastern Baltic. In the same period comprehensive research and monitoring of hard bottom macrozoobenthos and macrophytobenthos communities were initiated by Evgenij Pritkov, Aleksandr Korolev, Vladimir Muravsky, and Tatjana Kuznetsova. The work included mapping of macroalgae as herring spawning grounds in the Gulf of Riga and along the eastern Baltic coast and the assessment and short-term prognostication of the stock size and storm casts of the red alga Furcellaria as a raw material for the agar-agar industry in Latvia. Also the distribution and biomass of blue mussel communities as natural water purificators were monitored, and experimental artificial reefs for restoration of benthic biocenoses and herring spawning grounds were constructed. For these investigations a coastal station was established at Pape and a specially equipped boat, the Pikar, underwater TV, SCUBA diving, and aero-photo methods were used. 


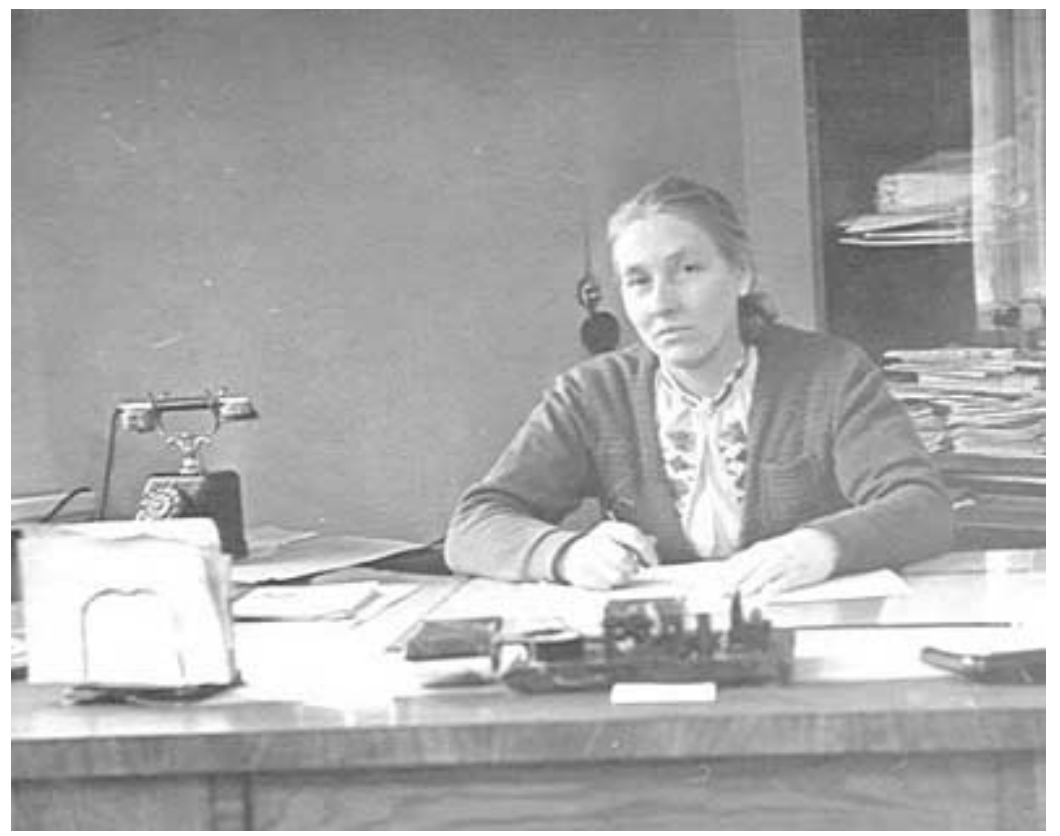

Photo 12. Austra Shurin (1906-78).

Mstislav Lishev (Photo 13) compiled an overview of Baltic salmon stocks and dynamics, as well as of the herring stock and fishery in the Gulf of Riga (Lishev, 1953, 1957; Lishev \& Rimsh, 1961). During the whole period of his work in the Latvian fisheries science (1945-87), he was a leader of the research into biocenotic complexes, modelling of the system "environment-organism-population", inclusion of the approach of multispecies trophic relations into the numeric stock assessment and prediction models, and introduction of limitation of catches. After the accession of the USSR to ICES in 1955, M. Lishev and I. Nikolaev were national experts in this organization. M. Lishev was a member of the Ichthyo-

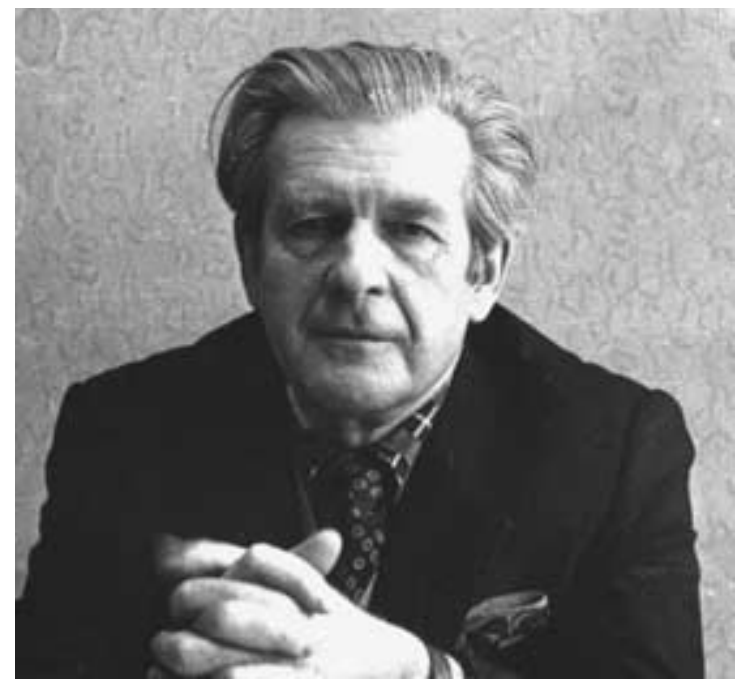

Photo 13. Mstislav Lishev (1920-90). 
logical Commission of the Academy of Sciences of the USSR and a member of the Editorial Board of the journal Voprosy ikhtiologii (1961-78). M. Lishev played a leading role at BaltNIIRH in preparing the Draft Fishing Rules of the International Baltic Sea Fishery Commission. He proposed and explained the necessary technical fishing regulation measures for herring, sprat, cod, salmon, flounder, and turbot in the East and North-East Baltic, enforced in 1973 . He initiated the catch limitation since 1963, starting with herring in the Gulf of Riga. M. Lishev had an important role in the functioning of the Baltic Fisheries Council (BFC), established in Riga in 1971, and in maintaining effective interrelations between the fisheries science, fishing industry, and administration in Latvia, Estonia, Lithuania, and Russia. The BFC allocated catch quotas for the Soviet Republics in accordance with the IBSFC catch quotas, decided on necessary changes in fishing regulation, gear, and rules as well as on fish restockings.

In the 1970s productive international cooperation of Latvian fisheries scientists developed. Based on the exchange of scientists, intercalibration of research methods, and coordination of surveys BaltNIIRH, the Institute of Marine Fishery and Fish Processing (IfH) of the GDR in Rostock, and the Polish Institute of Marine Fisheries (MIR) in Gdynia regularly collaborated in fish stock assessments and preparation of the respective forecasts. Later on the same data were used by relevant ICES fish stock assessment working groups. In 1991 the Agreement on Cooperation between BaltNIIRH and MIR was signed. The scientific results were published in joint editions by BaltNIIRH and IfH of the journal Fischerei-Forschung (1975-89), published in Rostock. In 1984 the Proceedings on Biological Productivity of the Baltic Sea, a three volume result of joint efforts of scientists of the USSR, Poland, and GDR, was published. In close cooperation within the ICES working groups, scientists of BaltNIIRH started composition of computerized numerical assessments and prognoses of stock size, fishing and natural mortality rates, and stock recruitment for the eastern Baltic cod, the open sea and Gulf of Riga herring, and Baltic sprat. The models of the virtual population analysis were applied. Here the contribution of the following scientists deserves special mentioning: M. Lishev, mathematicians Lev Ladizhenskij, Cand. Phys.-Math., Solomon Hozioskij, Cand. Phys.-Math., and Eduards Plūdonis, as well as the leading ichthyologists Ināra Lablaika, Cand. Biol., Biruta Jevtjukhova, Cand. Biol., and Faust Shvetsov, Cand. Biol.

I. Lablaika headed the group of researchers studying the complex of demersal fishes. She contributed much to establishing close links between the fisheries science and fishermen, arranging inter alia the system of catch statistics for scientific and practical use. Her own investigations dealt with the distribution, composition, and size of cod stocks as a response to the biological condition of fish, the state of the environment, and fishing (Lablajka et al., 1975).

Danute Uzars, Cand. Biol., was a leading scientist dealing with the feeding biology of the Baltic cod and the role of cod as a predator in the ecosystem (Uzars, 1994). Ëvalds Kondratovičs, Cand. Biol., investigated the biology, feeding, and growth of young cod and cod migrations, applying the tagging method. 
Tatjana Barānova, in collaboration with colleagues from MIR and IfH, conducted the research into the structure of cod otoliths, its ageing methods, and growth (Baranova \& Berner, 1984). Māris Plikšs together with Marğers Kalējs studied long-term relationships between the hydrographic regime and distribution and success of cod spawning, the role of the so-called spawning volume in the formation of cod stock recruitment. Vladimir Ipatov, Cand. Biol., worked on the physiology and biochemistry of cod. Māris Vītinš investigated the biology, populations, migrations, and stock size of flatfishes in the East and North-East Baltic (Vitinsh et al., 1975; Vitinsh, 1976), applied tetracycline injections in the studies on the increment of flounder otoliths, and followed the distribution of lymphocystosis of flounder in the East and North-East Baltic.

Investigations connected with the assessment and prognoses of the state of pelagic fish stocks were carried out under the leadership of B. Jevtjukhova (Evtjukhova et al., 1988). Fundamental regularities governing the formation of herring recruitment were established by Lidia Lisivnenko, Cand. Biol. and Helēna Trauberga, Cand. Biol., on the basis of monitoring herring larvae abundance, growth, and feeding, as well as data on zooplankton and temperature along the eastern coast of the Gulf of Riga in the 1950s-70s. During these investigations the Institute's field station in Salacgrìva was used as base. F. Shvetsov was a leading scientist in the research on Baltic sprat. In 1977 he started hydroacoustic surveys on pelagic fish stocks in the eastern Baltic, and since 1984 headed the Latvian participation in the ICES coordinated international hydroacoustic surveys on Baltic sprat stocks. Georgs Korņilovs, D. Biol., investigated the distribution, size, and productivity of herring spawning grounds in the Gulf of Riga.

The investigations by Galina Grauman, Cand. Biol., on the distribution, abundance, survival and morphometry of pelagic eggs and larvae of cod, sprat, flounder, and other fishes and on the spawning ecology and biology of these species in the areas of Bornholm, Gdansk, and Gotland basins (Grauman, 1984) are well known in the whole Baltic region.

In 1962-65, under the leadership of Vera Tanasaichuk, D. Biol., a special research programme on the productivity of the Gulf of Riga was carried out. In addition to investigations by A. Shurin, L. Lisivnenko, E. Kostrichkina, R. Line, and H. Trauberga, mentioned above, Ritma Gaumiga, Cand. Biol., studied the role of the ichthyoplankton runoff of the Daugava and Gauja rivers in the formation of the coastal ichthyofauna and productivity. H. Trauberga contributed to the programme with the research on three-spined stickleback and sand goby two fish species of small or no commercial value, but important elements of the ecosystem of the Gulf of Riga.

Jevgenijs Kairovs investigated the distribution of ichthyoplankton in the estuary of the Salaca River and conducted experiments on the introduction of new commercial fish species into the Gulf of Riga. In the 1960s, under his leadership and with the participation of E. Kostrichkina and A. Shurin, some batches of young Kaspian and Siberian sturgeons were released in the Gulf 
of Riga. In 1966-73 R. Gaumiga headed a group including R. Līne, L. Virsis, and E. Kondratovičs in implementing a complex research programme on the evaluation of environmental conditions and fish productivity of the water reservoirs of hydroelectric power stations on the Daugava River. Since 1974 the research in the Gulf of Riga on stocks of demersal fishes, including the abundance, protection, and fishery of eelpout, as well as on changes in the structure of biocenoses under the influence of environmental conditions was developed (Gaumiga, 1982; Gaumiga et al., 1997). The research in the Gulf of Riga was conducted in close cooperation with scientists of the Institute of Biology of the Latvian Academy of Sciences and with colleagues from the Tallinn Department. As a result of this cooperation the book Ecosystem of the Gulf of Riga between 1920 and 1990 was published by the Estonian Academy Publishers in 1995.

Fisheries investigations in Latvian lakes were initiated in 1947 by an expedition of the All-Union Research Institute of Lakes Fisheries (VNIORH) under the leadership of N. Savina. Hydrochemical conditions, fish food base, and ichthyofauna were studied in 12 lakes. The next expedition of VNIORH took place in 1952-53, when under the leadership of Prof. N. Mosevich the scientists of the Institute of Biology of the Latvian Academy of Sciences A. Kumsāre, O. Kačālova, R. Selkere-Laganovska, F. Pera, Z. Spuris, and J. Sloka investigated 13 additional lakes. Since then the inland waters research in Latvia was conducted by the Institute of Biology and later also by students of the Faculty of Biology of the Latvian State University, under the leadership of Prof. J. Lūsis, N. Sloka, V. Bodniece, and A. Rēdliha.

In 1960-72 BaltNIIRH performed a complex research on pond fisheries and commercial lakes (Pavel Nikitin, Nonna Ohrjamkina, and Jevgen̦ijs Rimšs). The methods and effectiveness of fertilizing ponds, combating fish diseases, productivity of lakes, and the prospects of stockings of young fish of valuable species were investigated. As a result practical recommendations on the management of ponds and lakes were given. In 1986 the Laboratory of Inland Waters of BaltNIIRH was established, headed by Rudīte Stalbe. Regular investigations on the hydrochemical regime, zooplankton and zoobenthos, fish growth, and species composition in lakes and elaboration of the biological basis for rational exploitation of lakes were started.

Elena Malikova, Prof., D. Biol. (Photo 14), worked at the Latvian Department of VNIRO and BaltNIIRH from 1951 to 1991. During 1955-63 she was director of the Institute. Malikova laid a scientific basis for artificial reproduction and intensive rearing of Baltic salmon smolts in Latvia and other Soviet Republics. She led a group of scientists working on fish feeding, growth, and rearing as well as on the determination of indications of the physiological and pathological condition of fishes. E. Malikova has written numerous scientific publications on the development of artificial feeds for salmonids and on the composition of the feeds (Malikova, 1953, 1967; Malikova \& Kotova, 1961). In the 1960s she composed moist feeds named "KRT" and in the 1980s, in collaboration with the Institute of Thermophysics of the Ukrainian Academy of Sciences, developed dry pellet feeds 
for salmon and rainbow trout, patented and named as "S-112-Lat". The fish feeds of BaltNIIRH were also used in rearing young sturgeons. The successors of E. Malikova were Nina Kotova, Cand. Biol., Uldis Jozepsons, Cand. Biol., the leading biochemist and researcher of biotechnology for salmon, trout, and hatchery rearing of other fishes, and Tatjana Glagoljeva, Cand. Biol., the fish physiologist, performing research on the evaluation of the health and viability of reared young salmon using haematological analysis. In the 1980s, based on E. Malikova's findings and under the leadership of Aḷgirdas Rusakjavičus, Cand. Biol., comprehensive research was conducted on the application of a method of farming rainbow trout in net-cages in Latvian lakes, rivers, and the Gulf of Riga. The method of

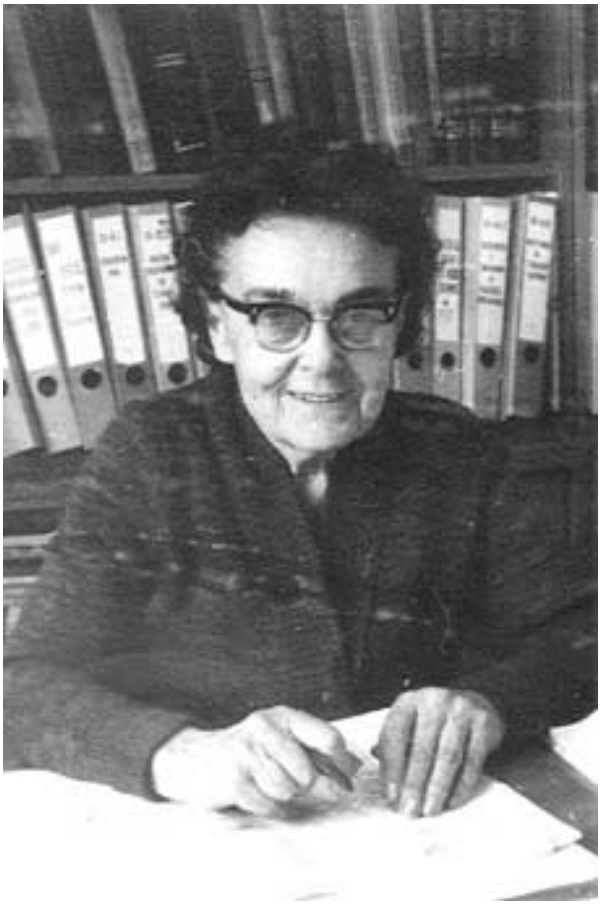

Photo 14. Elena Malikova (1909-97). commercial rearing of rainbow trout in warm geothermal waters was elaborated in the Institute's experimental base "Ragaciems" (1982-91). The main results of this research complex, headed by E. Malikova and A. Rusakjavičus, are summarized in two publications of BaltNIIRH $(1984,1991)$.

In the 1970s Jevgenijs Rimšs, Cand. Biol., and his assistants investigated the possibility of introducing chum salmon and pink salmon into the Baltic Sea. However, these releases, as well as experiments with the Caspian and Siberian sturgeons, were unsuccessful. From the end of the 1950s, the ecological background of the reproduction of migratory fish was investigated by Andis Mitāns, Cand. Biol. He studied mainly the river phase of salmon and sea trout, optimization of releasing and tagging hatchery smolts, dynamics of stocks, and regulation of fishery in the home waters and in the Baltic Sea (Mitans, 1970, 1975). In the 1980s-90s A. Mitāns initiated similar investigations on some other migratory fishes, and Nina Rjapolova developed a method of artificial reproduction of river lamprey. Jānis Peslaks, Cand. Biol., investigated the artificial reproduction of vimba bream and pike-perch in pond culture. Jānis Birzaks studied sea trout stocks, introducing electrofishing surveys on Latvian wild salmon parr and smolt populations in rivers. Oḷegs Vasins analysed the genetic diversity of salmon stocks and genetic limitations of artificial reproduction.

Important investigations of fish pathology and parasitology were initiated in the 1960s by Kārlis Vismanis, Cand. Biol. He started with the common carp 
pond culture, involving later on also wild fish - cod, flounder, and salmon in the sea, and eel in inland waters. A new nematode species - Philometra lusiana Vismanis - was discovered.

Research on fishing technology was started by Vasilij Kanin, Cand. Biol., who studied the development of trapnets for herring fishery in the Gulf of Riga (Kanin, 1953), and by Kir Yudanov, Cand. Biol., whose research interest was hydroacoustics in fishery. Electrofishing theory, methods, and techniques were developed by Juris Būmeistars, Cand. Tech., and Vulf Sternin, Cand. Tech., trawls selectivity and survival of escapes by Stanislav Shevtsov, D. Tech., Vladimir Kadnikov, Cand. Tech., and Vladimir Baturin, Cand. Tech.

During the whole postwar period Latvian fisheries scientists cooperated closely with their Estonian colleagues in the Tallinn Department of BaltNIIRH Linda Rannak, D. Biol., Evald Ojaveer, D. Biol., Vaike Erm, Cand. Biol., Ahto Järvik, Cand. Tech., Robert Aps, Cand. Biol., Ivar Veldre, Cand. Biol., Ilmar Sõrmus, Mart Kangur, Cand. Biol., Rein Tamsalu, D. Phys.-Math., Irina Shchukina, Tiit Raid, Cand. Biol., Henn Kukk, Cand. Biol., Mart Simm, Cand. Biol., Vello Kadakas, Cand. Biol., and others.

\begin{abstract}
AFTER 1991
On 4 November 1991, by the order of the Ministry of Fisheries of the Republic of Latvia, BaltNIIRH was reorganized into the Latvian Fisheries Research Institute (LATFRI) with Jevgeñijs Rimšs, D. Biol., as director in 1991 and Māris Vītiņš since 1992. The Institute included the Laboratory of Marine Biology (head Māris Plikšs), Section of Pelagic Fish (Georgs Kornilovs, D. Biol.), Laboratory of Aquaculture (Andis Mitāns, D. Biol.), Laboratory of Inland Waters (Rudīte Stalbe; the laboratory rejoined the Institute in 2000), Information Centre (Eduards Plūdonis), and the Scientific Library. The total scientific staff included 45 persons. According to Latvia's legislation, LATFRI is a governmental institution responsible for scientific advice for management, sustainable use, protection, and artificial reproduction of fish resources in Latvian waters in the open Baltic Sea, the Gulf of Riga, and the coastal zone as well as inland waters. To comply with this task, the Institute carries out comprehensive monitoring and research on hydrographic conditions, zooplankton, ichthyoplankton, benthos, young fish, spawning fish, fish feeding relations, populations and stocks, fish biology, physiology, parasitology, pathology, and genetics, effectiveness of fishing gear, catch structure, parameters of stock dynamics, artificial reproduction, wild populations of migratory species, fish stockings in the coastal zone, rivers, and lakes, and influence of fishing on seabirds and marine mammals. The Institute's last research vessel Baltijas Pètnieks ceased operating in 1993, therefore most marine surveys are performed on fishing vessels, using portable research equipment. For several specific surveys vessels of other institutions or foreign research vessels have been rented or used in the framework of cooperation.
\end{abstract}


The major developments of Latvian fisheries research and management during the last decade of the 20th century and the beginning of the 21st century are: close cooperation of the fisheries science and fishery practice, comprehensive investigations in the coastal zone, building and use of computerized scientific databases, incorporation of principles of multispecies, ecosystem, and precautionary approaches to stock assessment models and management, conservation of biodiversity, and intensive international cooperation.

Fruitful collaboration of LATFRI with other fisheries institutions is evidenced by Latvijas zivsaimniecības gada grämata (Latvian Fisheries Yearbook), issued regularly since 1996. It includes popular articles on fish fauna, state of stocks, commercial fishery and angling, fishing control, fishery legislation, as well as Latvian catch statistics since 1970. A valuable popular scientific book on Latvia's fish fauna was written by Plikšs \& Aleksejevs (1998).

On 23 September 1993, during the 81st ICES Statutory Meeting in Dublin, Ireland, the membership of Latvia in ICES was restored, with Māris Vītinšs, Director of LATFRI, and Normunds Riekstiņš, Director of the Latvian National Board of Fisheries, appointed delegates of Latvia to ICES (Photo 15). Since then

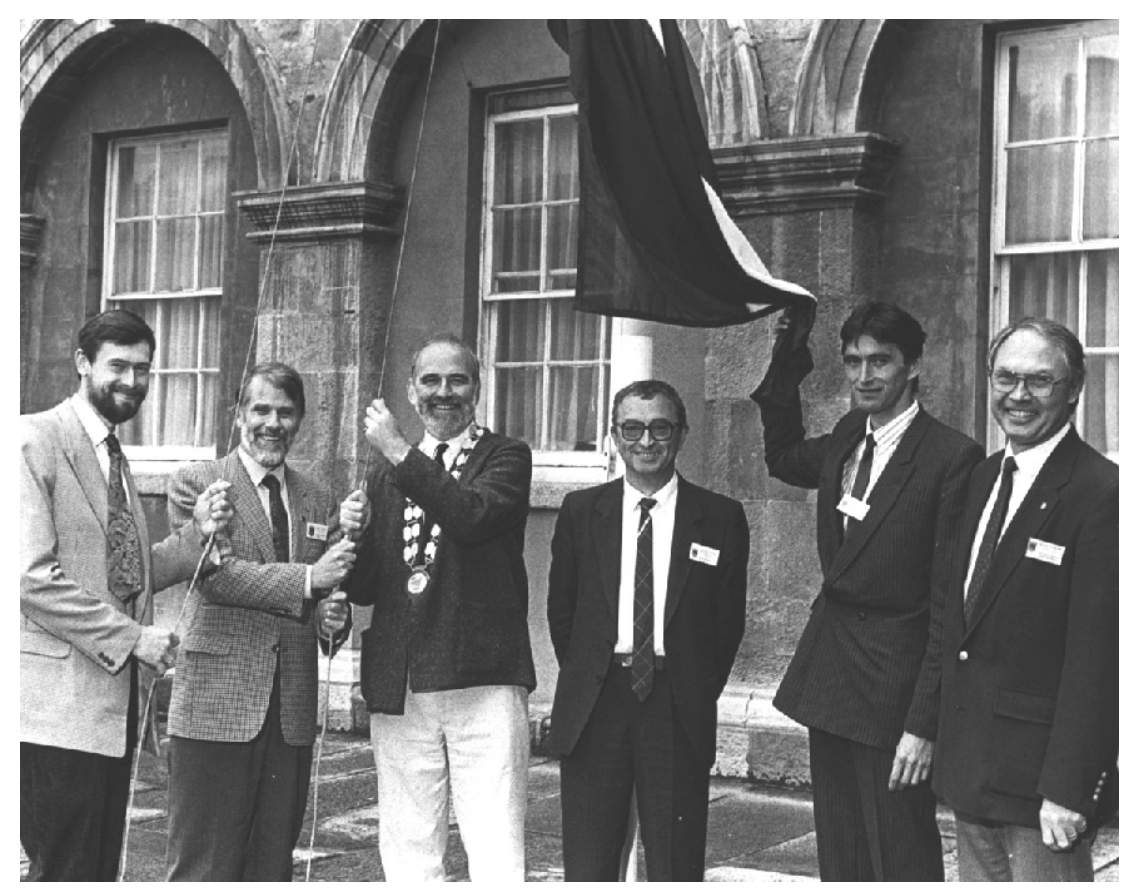

Photo 15. Hoisting of the flag of the Republic of Latvia in the Dublin Castle, Ireland, in honour of the re-accession of Latvia to ICES, during the 81st ICES Statutory Meeting on 23 September 1993. From left: Normunds Riekstinsš, Director of the Latvian National Board of Fisheries, Latvian Delegate in ICES; Māris Vītiņš, Director of the Latvian Fisheries Research Institute, Latvian Delegate in ICES; David de G. Griffith, President of ICES; Faust Shvetsov, scientist of LATFRI; Georgs Korņilovs, scientist of LATFRI, and Emory Anderson, General Secretary of ICES. 
the scientists of the Institute have participated actively in the committees, working and study groups of ICES, even as chairs of some of them, as well as in ICES coordinated international surveys in the Baltic Sea and in international research and technical development projects related to fisheries and environmental management. The results of scientific research are regularly reported at the ICES Annual Scientific Conferences and published in the ICES proceedings and other editions. LATFRI experts are giving important input into the work of the International Baltic Sea Fishery Commission and the Helsinki Commission. LATFRI has developed productive cooperation with institutes of fisheries research around the Baltic Sea.

\section{REFERENCES}

BaltNIIRH. 1984. Artificial Feeds for Intensive Production of Salmonid Fishes. Avots, Riga (in Russian).

BaltNIIRH. 1991. Aquaculture in Baltic. Avots, Riga (in Russian).

Baranova, T. D. \& Berner, M. 1984. Comparative results of investigation of otolith structure of cod from different areas of the Baltic. Fischerei-Forschung (Rostock), 22, 59-67 (in Russian).

Bērziņš, B. 1937. Retās zivis Rīgas jūras līcī. Daba un zinātne, 3, 81-83. Rīga.

Berzins, B. 1942. Hydrographische Untersuchungen der Hydrobiologischen Station im Rigaer Meerbusen und im Baltischen Meere. Folia Zool. Hydrobiol. (Riga), 11, 2, 361-369.

Cimermanis, S. 1998. Zveja un zvejnieki Latvijā 19. gadsimtā. Latv. Zināt. Akad. Vēstis (summaries in German and Russian).

Evtjukhova, B. K., Trauberga, E. F., Kostrichkina, E. M., Kaleis, M. V. \& Naglis, A. K. 1988. Long-term prognosing of herring year-class strength in the Gulf of Riga and the Eastern Baltic according to the system of environmental factors. Fischerei-Forschung (Rostock), 26, 14-18 (in Russian).

Fischer, J. B. 1791. Versuch einer Naturgeschichte von Livland, 2, Aufl. 24. Fridrich Nicolovins, Königsberg.

Gaumiga, R. J. 1982. The peculiarities of distribution and composition of stock of eelpout in the Gulf of Riga. In Rybokhozyajstvennye issledovaniya v bassejne Baltijskogo morya, Vol. 16, pp. 39-45. Avots, Riga (in Russian).

Gaumiga, R., Berzinsh, V. \& Urtans, E. 1997. Impact of environmental factors on fish community of the Gulf of Riga. In Proceedings of the 13th Baltic Marine Biologists Symposium, Jurmala, Latvia, pp. 205-210.

Grauman, G. B. 1984. Ichthyoplankton. In Ocherki po biologicheskoj produktivnosti Baltijskogo morya, Vol. 3, pp. 259-428. Moskva (in Russian).

Kaleis, M. V. \& Ojaveer, E. A. 1989. Main regularities of changes of environmental conditions and commercial fish stocks in the Baltic Sea. In Dolgoperiodnaya izmenchivost' uslovij prirodnoj sredy i nekotorye voprosy rybopromyslovogo prognozirovaniya, pp. 250-262. VNIRO, Moskva (in Russian).

Kaleis, M. V. \& Tamsalu, R. E. 1975. On modeling of the Baltic Sea. In Dinamika vod Baltijskogo morya, pp. 5-25. Estonskoe geograficheskoe obshchestvo, Tallinn (in Russian).

Kanin, V. F. 1953. Development of trapnet fishery in Latvian SSR. Tr. Latv. Otd. VNIRO, I, 42-63 (in Russian). 
Kawall, J. 1857. Der Strömling und sein Fang an der nordlishen Küste von Kurland. Das Inland (Dorpat), 46, 757-760.

Kostrichkina, E. M. 1968. Feeding relations of fishes in the Gulf of Riga. In Rybokhozyajstvennye issledovaniya v basseine Baltijskogo morya, Vol. 4, pp. 109-135. Zvaigzne, Riga (in Russian).

Kostrichkina, E. M., Ojaveer, E. A., Rannak, L. A., Yurkovskis, A. K. \& Yula, E. A. 1982. Longterm dynamics of the growth rate of herring in the Baltic Sea in relation to changes of oceanographic conditions and food supply. Fischerei-Forschung (Rostock), 20, 37-42 (in Russian).

Kostrichkina, E. M., Line, R. J. \& Sidrevics, L. L. 1989. Long term dynamics of zooplankton in the open part of the Baltic Sea during the period 1949-1984. In Osnovnye tendentsii évolyutsii ékosistemy. Mezhdunarodnyj proekt "Baltika". Problemy issledovaniya i matematicheskogo modelirovaniya ékosistemy Baltijskogo morya, 4, pp. 96-102. Leningrad (in Russian).

Kupffer, K. 1925. Zur einführung in die limnologische Literatur des heutigen Lettlands. Arch. Hydrobiol. Let. Suppl. (Stuttgart), 1, 63-68.

Lablajka, I. A., Lishev, M. N. \& Chozioskij, S. A. 1975. State, structure and exploitation of Baltic cod and its significance in the food chain. Fischerei-Forschung (Rostock), 13, 31-37 (in Russian).

Lishev, M. N. 1953. On relative abundance of Baltic salmon stocks. Tr. Latv. Otd. VNIRO, I, 29-36 (in Russian).

Lishev, M. N. 1957. Herring fishery in the Gulf of Riga. Tr. Latv. Otd. VNIRO, II, 3-18 (in Russian).

Lishev, M. N. \& Rimsh, E. J. 1961. Some regularities of abundance dynamics of Baltic salmon. $T r$. NII Rybn. Khoz., III, 5-103 (in Russian).

Ludvigs, P. 1940. Zvejniecība un zivkopība. In Latvijas zeme, zemnieki un viņu darbs, pp. 489502. Rīga.

Ludwig, F. 1908. Die Kustenseen des Rigaer Meerbusens. Arbeiten Naturforch.Veriens (Druck von W. F. Hacker, Riga), Neue Folge, Heft 11.

Malikova, E. M. 1953. Chemical content of some feed invertebrates. Tr. Latv. Otd. VNIRO, I, 213-224 (in Russian).

Malikova, E. M. 1967. On the elaboration of a method of accelerated rearing of salmon smolts in hatcheries. In Rybokhozyajstvennye issledovaniya v bassejne Baltijskogo morya, Vol. 3, pp. 146-193. Zvaigzne, Riga (in Russian).

Malikova, E. M. \& Kotova, N. I. 1961. Importance of antibiotics in artificial rearing of salmon smolts. Tr. NII Rybn. Khoz., III, 431-444 (in Russian).

Mansfeld, W. 1928. The occurrence and catch of salmonids in the Latvian coastal and inland waters. Conseil Intern. pour l' Exploration de la Mer., Rap. et Proc. Verb., V.XLVIII, $105-110$.

Mansfeld, W. 1930. Studien an Coregonen des Ostbaltikums. Archiv Hydrobiol., 21, 65-94.

Mansfelds, V. 1936. Latvijas zivis. In Latvijas zeme, daba un tauta, pp. 489-519. Rīga.

Mitans, A. R. 1970. The feeding of Baltic salmon smolts in the river and sea. Vopr. ikhtiol., 10, V.1 (60), pp.109-118 (in Russian).

Mitans, A. R. 1975. The efficiency of the natural and artificial reproduction of Baltic salmon as a result of specific ecology in the river phase of life. In Rybokhozyajstvennye issledovaniya $v$ bassejne Baltijskogo morya, Vol. 11, pp. 110-152. Zvaigzne, Riga (in Russian).

Mühlen, M. 1903. Fischerei verhaltnisse an der Kurlandischen Ostsee - Kuste. Balt. Wochenschrift, 53, 541-543.

Nikolaev, I. I. 1953a. Species composition of fishes of Latvian SSR. Tr. Latv. Otd. VNIRO, I, 5-27 (in Russian).

Nikolaev, I. I. 1953b. Phytoplankton of the Gulf of Riga. Tr. Latv. Otd. VNIRO, I, 115-172 (in Russian). 
Nikolaev, I. I. 1957a. On fluctuations of the biological productivity of the Baltic Sea. Tr. Latv. Otd. VNIRO, II, 83-113 (in Russian).

Nikolaev, I. I. 1957b. Biological seasons of the Baltic Sea. Tr. Latv. Otd. VNIRO, II, 115-140 (in Russian).

Nikolaev, I. I. 1961. Influence of plankton on distribution of Baltic herring and sprat. Tr. NII Rybn. Khoz., III, 201-223 (in Russian).

Ozoliņš, V. 1930. Usmas ezers. Limnologiisks apskats. Ģeog. raksti, Latv. geogr. biedr., 2, 68-78.

Plikšs, M. \& Aleksejevs, Ē. 1998. Zivis. Latvijas daba. Gandrs, Rīga.

Schneider, G. 1925. Die Süswasserfische des Ostbaltikums und ihre Verbreitung innerhalb des Gebietes. Archiv Hydrobiol., 16, 133-155.

Schneider, G. 1928. Die Seefischerei von Lettland und Estland. In Handbuch der Seefischerei Nordeuropas, Vol. 8, No. 6, pp. 1-34. Erwin Nägele, Stuttgart.

Schweder, G. 1884. Über die Fische der Ostsee, insbesondere die des Rigaschen Meerbusens. Korrespondenzblatt Naturforscher-Vereins (Riga), 27, pp. 14-17.

Shurin, A. T. 1957. Feeding areas of flounder Pleuronectes flesus trachurus Dunker in the Gulf of Riga. Tr. Latv. Otd. VNIRO, II, 141-156 (in Russian).

Shurin, A. T. 1961. Groups of benthic fauna of the Gulf of Riga. Tr. NII Rybn. Khoz., III, 343-368 (in Russian).

Shurin, A. T. 1968. State of the benthic fauna from 1900 to 1962 in the changing conditions of the Baltic Sea. In Rybokhozyajstvennye issledovaniya v bassejne Baltijskogo morya, Vol. 4, pp. 61-88. Zvaigzne, Riga (in Russian).

Sloka, J. 1985. Akmens laikmetā zvejotās zivis zvejnieku II apmetnē. LPSR ZA Vēstis, 7, 110-116.

Stakle, P. 1931. Hidrometriskie novērojumi Latvijā līdz 31. X 1929. Jūrniecības Departaments, Rìga (in Latvian and French).

Strand, E. \& Ozoliņš̆, V. 1931-1934. Hydrographische Untersuchungen der Hydrobiologischen Station im Rigaer Meerbusen und im Baltischen Meere. Folia Zool. Hydrobiol. (Riga), III-V.

Uzars, D. 1994. Feeding of cod (Gadus morhua callarias L.) in the Central Baltic in relation to environmental changes. ICES Mar. Sci. Symp., 198, 612-623.

Vitinsh, M. J. 1976. Some regularities of distribution and migrations of flounder (Platichthys flesus L.) in the Eastern and North Eastern Baltic. Fischerei-Forschung (Rostock), 14, 39-48 (in Russian).

Vitinsh, M. J., Chozioskij, S. A. \& Lishev, M. N. 1975. Methods of research and dynamics of flounder stocks in the Eastern and North Eastern parts of the Baltic and required measures of catch regulation. Fischerei-Forschung (Rostock), 13, 39-46 (in Russian).

\section{LÄTI KALANDUSUURINGUTE AJALUGU}

\section{Māris VĪTIN̦Š, Ritma GAUMIGA ja Andis MITĀNS}

On kirjeldatud Läti mere- ja kalandusuuringute arengut alates 18. sajandist. Vaadeldud on uurimissuundi ja -asutusi, tähtsamaid teadlasi ja publikatsioone ning nende kohta Läti ja rahvusvahelises teaduses. 18.-19. sajandil koguti teadmisi peamiselt veekeskkonna ja vee-elustiku (k.a. kalade ja kalanduse) kohta. Hilisemas arengus olid tähtsateks sündmusteks I Läänemere kalanduskongress Riias 1910. aastal, Läti saamine Rahvusvahelise Mereuurimise Nõukogu (ICES) 
assotsieerunud liikmeks 1923. aastal ning täisliikmeks 1937. aastal. 1945. aastal koondati Läti mere- ja kalandusuuringud ühte asutusse, mis arenes Läti Kalandusuuringute Instituudiks. Instituut korraldab nii kalanduslikke ja kalakasvatuslikke kui ka veekeskkonna ja hüdrobioloogia alaseid uuringuid, samuti seiret ja modelleerimist. On saavutatud hea koostöö teiste maade teadlaste ning rahvusvaheliste organisatsioonidega (ICES, Läänemere Kalanduskomisjon, Helsingi Komisjon jt.). 